
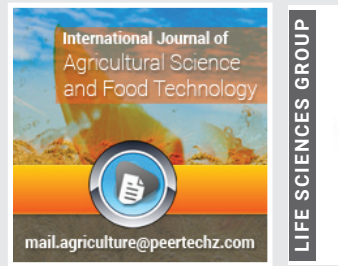

\title{
Value chain analysis of
} smallholder milk producer in

\section{West Hararghe Zone, Ethiopia}

\section{Azeb Lemma Kebede* Adune Dinku and Mohammed Sheko}

School of Agricultural Economics and Agribusiness, Oda Bultum University, Chiro, Ethiopia

Received: 30 May, 2020
Accepted: 30 June, 2020

Published: 02 July, 2020

*Corresponding author: Azeb Lemma Kebede, School of Agricultural Economics and Agribusiness, Oda Bultum University, Chiro, Ethiopia, Tel: +251920913784; E-mail: azeblemma13@gmail.com

Keywords: Value chain; Heckman two-stage; Value chain actors

https://www.peertechz.com

\section{Check for updates}

\begin{abstract}
The study was aimed at analyzing milk value chains in West Hararghe zone with 140 producers were randomly selected from list of dairy producer kebeles. Meanwhile, 30 traders from different markets and 30 consumers in Chiro, Bedessa Gemechis and Mieso towns were selected and interviewed. Heckman two stage models were applied to identify determinants of milk market participation and volume of milk supply to the market. The results shows among those variables hypothesized to affect milk market participation decision, distance to the nearest market, crop income and age of household head were negatively and significantly affecting participation decision and also livestock unit is affect participation decision significantly and positively. Land size, improved dairy cows, livestock unit were significantly and positively influencing the value of milk marketed. The value chain analysis revealed that the major value chain actors are input suppliers, producers, collectors, rural and urban wholesalers, retailers, cafes and consumers. It is also found that milk passes through several intermediaries with value added products (boiled milk and yoghurt) before reaching the ultimate users. Therefore, policies aiming at increasing producer's provision of modern inputs, number of milk cows and improving livestock production of milk cows and change of their attitudes towards milk production and processing, participating to dairy market were recommended to accelerate milk value chains development in the study area.
\end{abstract}

\section{Introduction}

The estimate of cattle for the rural sedentary areas at country level is about 53.4 million. About $64 \%$ or 34 million of these are aged 3 years or above and play a number of economic roles in the livelihood of smallholder farmers. Livestock is primarily kept on smallholdings where it provides draught power for crop production, manure for soil fertility, fuel and serves as a source of family diet and source of cash income (from sale of livestock and livestock products) particularly when markets for crops are not favorable [1].

Dairy production is crucial in Ethiopia as milk and milk products are important source of food and income. Despite the huge potential, dairy production has not been fully exploited and promoted in the country. A number of factors such as use of traditional technologies, limited supply of inputs (feed, breeding stock, artificial insemination and water), inadequate extension service, poor marketing infrastructure, lack of marketing support services and market information, limited credit services, absence of producers' organizations, and natural resources degradation [2] have contributed to unexploitation of dairy potential. In addition, policy decision on assurance of quality and standards, product marketing, among others is taken in the absence of vital information on how they affect the entire value chain [3].

Like most developing countries in Africa, Ethiopia did not have a clear livestock and livestock development policy for many years up until the establishment of Livestock Marketing Authority (LMA) in 1998. Furthermore, dairy product marketing channels and their characteristics have not yet been studied and analyzed for different parts of the country. Earlier studies on local and regional dairy products market in the country include [2-6] Hence, the study area of West Hararghe has high milk production marketed without further processing to other products. This implies that producers at farm level not get appropriate profit share than other intermediary. Even if, there were high production of milk there were no studies in the study area related to milk value chain analysis since milk value chain studies become essential to provide vital and valid information on the operation and efficiency of dairy product 
marketing system, for effective research, planning and policy formulation. Knowing the behaviour of each actor from input suppliers to the ultimate consumers would be give information to solve problems and give ultimate solution. Therefore, in line with the market-oriented production strategy of the country's policy, the study is intended at bridging the information gap with regard to milk value chains, factors affecting milk supply and to participate in the milk market and to access the profit margin of different actors in West Hararegie Zone, Ethiopia.

\section{Data and methods}

\section{Description of the study area}

The study was conducted in West Hararghe zone, Oromia National Regional State of Ethiopia and the capital city of the Zone is located about $326 \mathrm{~km}$ east of the capital city of Addis Ababa along the main road. Based on the population projection value (2018) report, West Hararghe has a population of $1,951,706$, an increase of $47.16 \%$ over the 1994 census, of whom 989,861 are men and 961,845 women; with an area of 15,065.86 square kilometers, the zone has a population density of 124.23. While 160,895 or $9.36 \%$ are urban inhabitants, a further 10,567 or $0.56 \%$ are pastoralists. The topography of West Hararghe is characterized by steep slopes in the highlands and midhighlands and large plains in the lowland areas. The highlands and mid-highlands are normally extensively cultivated but only partially protected by soil conservation structures and practices such as grass strips, alley cropping and bench terraces. The Zone is characterized by crop-livestock mixed farming system where livestock in general and dairy production in particular contribute significantly to farmer livelihoods used as cash income generating purpose. Local cattle are the predominant breeds in the study area. Market oriented dairy production based on local dairy cows is also practiced. The study area has high production of milk potential in and selling to the district areas. The major crops grown in the area are food barley, wheat, sorghum and Khat production. Khat and Coffee is an important cash crop of this Zone. Over 50 square kilometers is planted with this crop of coffee and the climatic condition is conducive to livestock production.

\section{Sample size and sampling technique}

For this study, a representative sample was selected by using multi stage random sampling technique to select milk producer kebeles and sample milk producer households. In the first stage from twelve milk producer districts, three of them were selected randomly. In the second stage nine kebeles are selected randomly based on probability proportional to size of kebeles in the districts and finally 140 producers were randomly selected from list of dairy producer based on probability proportional to size of milk producers households in the kebeles. Interviewed sample size is determined using a simplified formula provided by [7] provided below.

The interviewers of sample traders were selected randomly counting from different markets based on different characteristics and 30 traders were selected from the three districts with probability proportional to size of the traders in the district.
Dairy product consumers were interviewed from Meiso, Chiro, Qunii, and Bedessa cities randomly. And a total of 30 households were selected from those cities. The total sample size of 200 was used for this study including producers, traders and consumers.

$$
n=\frac{N}{1+N\left(e^{2}\right)}
$$

Where: $\mathrm{n}=$ sample size,

$\mathrm{N}=$ Population size $\quad \mathrm{e}=$ sampling error/ level of precision $=$ $7 \%$ were used

\section{Data type and methods of data collection}

Both primary and secondary data types were used in the study under investigation. Primary data were collected using two types of structured questionnaire, one for milk producer farmers and the other for milk traders. A preliminary survey was also conducted through focus group discussions (guiding key informant's checklist) to obtain general information that could not be collected from dairy producers and traders of interviews. Primary data collected from households were focused on factors affecting milk market participation decisions, volume of marketed milk supply and general behavior of different value chain actors. Secondary data were also collected from journals, books, CSA, district reports and other organizations.

\section{Methods of data analysis}

Descriptive statistics such as such as means, percentage and total gross marketing are used to analyze demographic and socio-economic characteristics of smallholder milk producers.

\section{Market performance analysis}

[8] defines market performance as to how well the market fulfills certain social and private objectives. This includes price levels and price stability in long and short term, profit levels, cost, efficiency and qualities and quantity of food commodities'. Because precise costs are frequently difficult to determine in many agricultural marketing chains for the reasons that costs are often cash and imputed, the Total Gross Marketing Margin (TGMM) is required to be calculated (Scott, 1995). It is expressed as a percentage of the difference between end buyer and first seller prices (Mendoza, 1991).

$$
T G M M=\frac{\text { Endbuyerprice }- \text { firstsellerpice }}{\text { End buyer price }} \times 100
$$

Where, TGMM=Total Gross Marketing Margin

The producer's margin is calculated as a difference:

$$
\text { GMMp }=\frac{\text { Endbuyerprice }- \text { markeringgrossmargin }}{\text { End buyer price }} \times 100
$$

Where GMMp= the producer's share in consumer price or $\mathrm{PS}=\frac{p p}{c p}=1 \frac{M M}{c p}$ 
Where: PS=producers share

$\mathrm{Pp}=$ producers price

$\mathrm{Cp}=$ consumer price

$\mathrm{MM}=$ marketing margin

\section{Market participation equation}

Models that include whether milk producing smallholder farmers participate in the market or not participate. In such circumstances, the probit model estimation is employed.

The Probit model is specified as:

$Y_{1 i}=X 1 i \beta+u_{1 i} u_{1 i} \sim N(0.1)$

MMP $=1$, if $Y_{1 i}>0$ or (Participated)

$\mathrm{MMP}=0$, if $Y_{1 i} \leq 0$ (Not participated)

Where $Y_{1 i}$ is the latent dependent variable which is not observed, Participated or not participated

$X_{1 i}$ - is vectors that are assumed to affect the probability of sampled dairy household milk market participation.

$\beta_{1}-$ is vectors of unknown parameter in participation equation

$u_{1 i}-$ are residuals that are independently and normally distributed with zero mean and constant variance.

The observation equation/the supply equation

Heckman selection model was used for analysing factors affecting sales volume of dairy. This model estimates volume of milk supplied to the market by smallholder milk market participants [9].

The model is specified as:

$$
\mathrm{MMV}=Y_{2 i}=X_{2 i} \beta_{2}+u_{2 i} u_{2 i} \sim N\left(0, \delta^{2}\right)
$$

$Y_{2 i}$ is observed if and only if $M M P=1$. The variance of $u_{1 i}$ is normalized to one because only $M M P$, not $Y_{1 i}$ is observed. The error terms, $u_{1 i}$ and $u_{2 i}$, are assumed to be bivariat, normally distributed with correlation coefficient, $\delta, \beta_{1}$, and $\beta_{2}$ are the parameter vectors.

$Y_{2 i}$ is regressed on the explanatory variables, $X_{1 i}$, and the vector of inverse Mills ratios ( $\lambda i$ ) from the selection equation by ordinary least squares.

where: $Y_{2 i}$ is the observed dependent variable it is the volume of supply in the second-step

$X_{2 i}$ is factors assumed to affect sale volume

$\beta_{2}$ is vector of unknown parameter in the supply equation

$u_{2 i}$ is residuals in the supply equation that are independently and normally distributed with zero mean and constant variance.

$$
\lambda=\frac{f(\chi \beta)}{1-F(\chi \beta)}
$$

$f(x \beta)$ is density function and $1-F(x \beta)$ is distribution function

\section{Results and Discussion}

\section{Demographic and socio-economic characteristics of sample households}

Milk product movement: The primary objective of milk production for farmers in the district was for cash income generating and family consumption of dairy products. In table below indicated sample milk households produced 905.41 liters of milk per year. Most of the milk produced sold to the market as raw milk, which accounts on average of 560.08 litres or as 61.88 percent households. Out of produced milk 326.63 liters (34.95\%) was used as home consumption with no further processing. The remaining $3.17 \%$ of milk was processed to butter for cosmetic purpose of household members Table 1.

Table 1: Types of dairy products produced and utilized by sample farm households per household/year.

\begin{tabular}{|c|c|c|}
\hline Dairy products & Litres & Percent \\
\hline Amount of row milk consumed at home & 316.63 & 34.95 \\
\hline Amount of row milk supplied to the market & 560.08 & 61.88 \\
\hline Amount of milk processed to butter & 28.7 & 3.17 \\
\hline Total milk produced by sample households & 905.41 & 100 \\
\hline
\end{tabular}

Source: Computed from survey data, 2019

Actors, their roles, and relationships in milk value chain: The competitiveness of value chain is greatly influenced by the partnership and collaboration for innovation that can be realized by value chain actors [10]. Value chain actors include direct chain actors, which commercially involved in the chain and indirect actors, which provide financial or non-financial support services. The survey result shows that the dairy value chain actors in the study area are input suppliers, producers, collectors, rural wholesalers, urban wholesalers, retailers, cafes and ultimate consumers. Chain actors and their roles are described as follows.

Input suppliers: At this stage of the value chain, many actors are involved directly or indirectly in agricultural input supply in the study area. Accordingly, inputs such as AI (Artificial Insemination), veterinary services, hybrid Borena cows, improved forage and pasture seeds, among others have been obtained from Agricultural office of the district. Even if, there was AI in agricultural support, supply of this input is not enough and available for rural kebeles which is long distance at the district town. In addition, awareness of dairy farm producers about improved cows' advantage was also very low because of inadequate extension contact or lack of training opportunity.

Producers: Milk producers are the second link along the milk value chain actors, who decides on how to produce and 
for whom to sell their produced milk products. Milk producers are the major actors who perform most of the value chain functions right from farm inputs preparation including buying of dairy cows or procurement of the inputs from other sources to handling and marketing. The major value chain functions that milk producers perform include feeding of their milk cows, cleaning of their milk cow barn, controlling and taking to veterinary services, harvesting or milking and transporting to purchasers of the product of different value chain actors. Majority of producers were selling their row milk to collectors and others of were also selling directly to consumers and retailers.

Milk producers of the study area mostly organized by local name /Ekub/, which is used to save time, to decrease transport cost and labour cost these is highly effective in Gemechis District. Those producers supply their milk to those members based on their order. The collected milk sells to their customers of collectors, retailers and for other consumers on average for the price of $21 \mathrm{Birr} /$ litre. In summer season, even if production of cow's milk and milk products increased, but the price were low the producer who gets because of high production of dairy products on the market. Because those traders set the purchase price and production cost of dairy cows were very high resulting into less benefit from selling of this products. Feeding milk cow's price increasing, lack of modernized milk container to transport the market, and absence of dairy cooperatives were the main constraints in the study area. Shortages of grazing land and water in accessibility were problems, which affects milk participation decision and level of milk marketed. Even if, there were no extension and other training opportunities but the existence of well experienced farmers by their traditional and developed indigenous livestock management system, the rational power share that have women have in the milk production and marketing business in the study area was the main opportunity for different value chain actors. The current initiation done by the government to develop infrastructures relevant to livestock development and develop disseminate breed types was also the main opportunities for participants and non-participant of dairy producers.

Local collectors: These traders in assembly markets collect raw milk from milk producers in local kebeles milk markets for reselling it to rural wholesalers, café, retailers and consumers directly. They use their own financial resources to buy milk from the surrounding area. They play important role for those producers to join them for other value chain actors in the milk value chain for the study areas. Collectors are the actors responsible for the trading of milk from production areas to other actors of different market. The value adding activities of collectors include buying, assembling and selling to different value chain actors.

Furthermore, local collectors stated that lack of testing quality like including water and other similar color products, adulteration were the major problems in their buying and selling activities. In addition, from the sample kebeles, the most severe problems were lack of transportation access, high transportation cost, lack of modernized milk transporting container, spoilage cost were the main constraints.
Rural wholesalers: Rural wholesalers are mainly involved in buying raw milk from merely collectors and selling to different value chain actors. These are suppliers of bulk of milk products to urban wholesalers, retailers and cafes after boiling and based on their customer demands fulfilling their container of jerkin of three litres then transport to Chiro and Qunni, from Gemechis, and to Chiro and Bedessa from Oda Bultum and to Chiro from Mieso sometimes to Awash from Mieso. Survey result indicates that three of rural wholesalers were found in the district market. Chiro city is the main assembly center for milk from collectors in their surrounding rural kebeles of the three districts. They have high supply and quality milk products from those sample kebeles. Hence, for those kebeles of rural wholesalers have an opportunity to get high supply of milk from these two kebeles such as Kasheja and Kuyobo, which is a remote area, but high quality milk were supplied from these areas. Lack of support from governmental or nongovernmental organizations, high transport cost, inability to extend shelf life of milk products, poor transporting and packing material are among the major problems for those rural wholesalers.

Urban wholesalers: Urban wholesalers are those who reside in terminal market of Chiro, Bedessa and sometimes from Awash buy processed or value added and unprocessed milk from rural wholesalers of Gemmechis, OdaBultum and Mieso districts directly from other collectors. At present, urban wholesalers are major milk suppliers to retailers and cafes of Chiro and Bedesa because of transport cost, loading and unloading cost and other costs the price were very different from rural wholesalers and transporting vehicle transport were let so, they face a problem of deteriorate milk and they get loss of profit like other traders. They have an opportunity of access of transportation as supplying milk from other markets of their customers and taking milk container again for them. This transportation system decreases their transportation cost, energy, time, and may enable them to involve in other economic income activities.

Retailers: Retailers involvement in the chain includes buying of milk directly from, producers, collectors, urban and rural wholesalers and selling directly to consumers. The retailers mostly whom they have shops and refrigerator have selling by value adding to other product form of yoghurt. Others sell without further processing. Directly consumers by value adding of yoghurt and further processing of boiling milk again to control quality. Retailers are key actors in dairy value chain in the district and town of Bedess and Chiro. They are the last link between producers and consumers other than cafes. Consumers usually buy the product from retailers as they offer according to requirement and purchasing power of the buyers. Retailers can be divided in to urban and rural. In the case of rural, retailers are based in village market and mainly purchase milk from farmers, and sell to consumers. Urban retailers purchase from urban wholesalers and sell to urban consumers. They have an opportunity because of high demand of dairy products in their area. They also have an opportunity as customers of urban wholesalers are there.

Cafes: Are the last link of selling for consumers. Based on the survey result shows, that majority of cafes buy milk from 
collectors, rural wholesalers and urban wholesalers. Most of them were further process to yoghurt and boiling to drink and sell directly to consumers. Comparably, the prices were high from other value chain actors.

Consumers: Consumers are the last value chain actors of those purchasing the products for consumption purpose only. Milk products are consumed by the people of the district or transported to other parts of the towns and be consumed by others. It is taken either alone or with other foodstuffs. The survey result showed that from milk products most of consumers used were raw milk. Those consumers purchase milk and ergo directly, from producers, retailers and cafes though most of the consumers purchase from retailers. Consumers mostly consumed by paying high price because of passing different value chain actors they may also loss their purity of milk except in Oda Bultum districts there is Union that is called car Oda Bultum Union supplying milk for the kebeles people and Bedesa, city at low price some times when the production is high the union also supply to Chiro for some customers also. Respondents' consumers from Chiro, Bedesa, Miesso and Quni they indicated that lower quality, high price and shortage of supply in dry season were the most severe problem.

Value chain governance: The dominant value chain actors play facilitation role. They determine the flow of commodities and level of prices. The study result indicated that rural wholesalers govern the whole milk. Rural wholesalers usually have strict quality standards/parameters/ by their traditional testing methods and expect their milk suppliers to meet these standards. Rural wholesalers fix the price based on purchasing price and processing cost. Rural wholesalers are always complaining that those collectors are not providing quality milk and while collectors blaming the wholesalers for offering low prices and sharing loss.

Producers are not governing the value addition chain. Hence, they are price takers. Therefore, producers do not get maximum benefit from selling row milk. The survey result shows that milk value chain actors have no trading licenses except in Gemechis district one cooperatives have license and those cafes in the study areas have license. Even if, there were no trading licenses and initial working capital requirement is low to inter milk marketing, those experienced traders create a barrier to inter this milk value chain actors.

Milk market performance: The performances of milk market were evaluated by considering associated costs, returns and marketing margins. The marketing margin refers to the difference between retail price and farm gate price. The marketing cost of the milk mainly involves the transportation cost of activities incurred before reaching the consumer. Marketing margin can be used to measure the share of the final selling price that is captured by a particular agent in the value chain. In order to calculate the marketing margin of an agent, the average price of milk for that particular agent was taken. Marketing margins, associated costs and benefit share of value chain actors and marketing margins through different main channels were presented bellow Table 2 .
Table 2: Marketing costs and benefits of different milk value chain actors (Birr/litre).

\begin{tabular}{|c|c|c|c|c|c|c|}
\hline Cost items & Producers & Collectors & $\begin{array}{l}\text { Rural } \\
\text { whole } \\
\text { sellers }\end{array}$ & $\begin{array}{l}\text { Urban } \\
\text { whole } \\
\text { sellers }\end{array}$ & Retailers & Cafes \\
\hline Purchase price & - & 15 & 19 & 24.7 & 29.7 & 36 \\
\hline Production cost & 12 & 0 & 0 & 0 & & 0 \\
\hline Transportation cost & 0.06 & 0.4 & 0.6 & 0.26 & - & - \\
\hline $\begin{array}{l}\text { Cleaning of } \\
\text { containers }\end{array}$ & 0.011 & .02 & 0.05 & 0.028 & 0.005 & .008 \\
\hline $\begin{array}{l}\text { Spoilage and loss } \\
\text { cost }\end{array}$ & - & 0.03 & 0.06 & 0.05 & .0009 & - \\
\hline $\begin{array}{l}\text { Loading and un } \\
\text { loading cost }\end{array}$ & - & - & - & 0.5 & - & - \\
\hline Telephone & - & 0.02 & 0.16 & 0.25 & 0.05 & 0.1 \\
\hline $\begin{array}{l}\text { Processing/boiling/ } \\
\text { cost including wood } \\
\text { of perfume }\end{array}$ & 0.02 & 0.005 & 0.476 & - & 0.19 & 0.91 \\
\hline Labour cost & 0.08 & - & 0.124 & .06 & 0.17 & 0.35 \\
\hline $\begin{array}{l}\text { Buying milk } \\
\text { container }\end{array}$ & 0.0015 & 0.0008 & 0.0014 & 0.001 & - & - \\
\hline Total cost per litre & 12.167 & 15.581 & 19.58 & 25.729 & 30.42 & 38.84 \\
\hline Selling price & 15 & 19 & 24.7 & 29.7 & 36 & 47.33 \\
\hline Profit margin & 2.83 & 3.42 & 4.42 & 3.97 & 5.58 & 8.49 \\
\hline
\end{tabular}

Source: Computed from survey data, 2019

\section{Econometric result}

Determinants of milk market participation: The Heckman's procedure results for both outcome and selection variables are presented and discussed below. Moreover, it is important to check multicollinearity problem before running the model for continuous variables. VIF for the variables was in the ranges of 1.16-2.63. The result shows that multicollinearity was not a problem among the hypothesized variables (Appendix Table 1, 2) Table 3.

Age of household head: As hypothesized, it influenced milk market participation decision negatively at five percent significance level. The marginal effect revealed that when the household age increases by one year, the probability of participating in the milk market decreases by 2.56 percent. As realty aged households may have shortage of labour force to milk production and marketing activities those households are instead of selling and generating cash, they prefer consuming row milk. This study result resembles the findings of [26].

Distance to the nearest market: It was hypothesized that it influences milk market participation decision negatively. This variable was found significant to influence participation decision in milk market negatively at less than one percent significant level negatively. This implies that as dairy producer residents distance increases by a kilometre from the milk market, the probability of participation decision to the market decreases by 7.5 percent. This may imply that milk product is perishable and hence it may not be marketed to long distance markets. This finding is consistent with that of [11].

Crop income: Previously it was hypothesized that crop income affect milk market participation positively. It influences 
Table 3: First step heckman selection model with marginal effects.

\begin{tabular}{|c|c|c|c|}
\hline Variables & Coefficients & Std. Err & Marginal effect \\
\hline SEX & .768233 & .933351 & .070172 \\
\hline AGE & $-.163268 \star \star$ & .065422 & -.025641 \\
\hline HH size & -.319329 & .2772534 & -.028831 \\
\hline EDU & -.135373 & .2773695 & -.012222 \\
\hline LAND & -.1274489 & .1525195 & -.010644 \\
\hline NMC & 1.089878 & .7360185 & .098399 \\
\hline AINFO & .677342 & .7386585 & .061154 \\
\hline FARMI & -.323289 & .0276234 & -.014741 \\
\hline ACEXT & -.2141931 & .5794601 & -.019338 \\
\hline CROPI & $-3.211101 \star$ & 1.651632 & -.298923 \\
\hline HYBR & 1.554085 & 1.860134 & .140311 \\
\hline DNM & $-.0942235 \star \star \star$ & .3690459 & -.0752754 \\
\hline TLU & $3.069039 \star \star *$ & 1.076004 & .277088 \\
\hline cons & 37.32742 & 12.62674 & \\
\hline
\end{tabular}

Note: $* * *, * *$ and * at $1 \%, 5 \%$ and $10 \%$ indicate statistically significance level respectively. Source: Model output based on survey data, 2019

participation of milk market significantly and negatively at less than ten percent significance level. This is because if crop income of households is adequate for their consumption and economically enough, household do not sell their milk and milk products to the market this finding is similar with the finding of [3]. Since, the result revealed that as income from crop increases by one percent participation decision of milk to the market decreases by the predicted value of 30 percent.

Tropical livestock holding: This variable was found to influence the probability of participating in the milk market positively and significantly at one percent significance level. Livestock are important sources of cash in dairy households to purchase different input; this finding is consistent with the finding of $[2,12]$. The marginal effect revealed that when the TLU increases by one unit, the probability of participating in the milk market increase by 27.7 percent.

Determinants of level of participation in-farm level milk marketing: According to [9] a sample selection bias refers to the problems where the dependent variable is only observed for a restricted and non random sample.

Inverse mills ratio (LAMBDA): The p-value of this variable is 0.012 as presented in table below this implies that the correction for selectivity bias is highly significant at less appropriate for this data and Mill's ratio corrects biased. Hence, this result suggests that there appears to be unobserved factors that might affect negatively both probability of dairy household market entry decision and marketable milk volume.

Land size: As expected, this variable influences milk market volume positively and significantly at five percent. The result shows that, the availability of land enables the owner to earn more agricultural output, which in turn increases the marketable supply. The implication is that as the farmer use more land for crop production more output is obtained and the residue also used for the feed of animals and also enables farmers to buy more cows and result in increases volume of milk production and this indirectly increases the volume of milk supplied to the market so the coefficient shows that as land size increases by one hectare leads to 25.87 litres increase in volume of milk marketed. This finding is consistent with that of $[3,4]$.

Tropical livestock unit: This variable was found to influence the volume of milk marketed positively and significantly at five percent significance level. The implication of the result was that livestock are important sources of cash in dairy households to purchase supplementary feeds when feed becomes shortage from their own land and in dry season. In addition as the number of cows increase, milking period may increase and milk marketed volume increase. Thus, the coefficient shows that a unit increase in tropical livestock unit lead to 128.82 litres increase in volume of milk marketed. This study result is consistent with the findings of [2].

Improved milk cows: As expected hybrid milk cows indicates a positive estimated coefficient which is significant at one percent significance level. This implies that as compared to non owners of hybrid milk cows the household who have hybrid dairy cows, milk marketed to the market increases by 682.2 litres per year. This finding is consistent with that of [3,13-32] Table 4 .

Table 4: Estimates of level of participation.

\begin{tabular}{|c|c|c|c|}
\hline Variables & Coefficient & Standard Deviation & p-value \\
\hline AGE & -.510717 & 2.425878 & 0.874 \\
\hline HH Size & 11.68114 & 20.54922 & 0.603 \\
\hline EDU & -8.307653 & 21.83056 & 0.704 \\
\hline SFD & 6.532357 & 20.13764 & 0.746 \\
\hline LAND & $25.87701^{\star}$ & 12.83852 & 0.072 \\
\hline DNM & -18.78078 & 224.8759 & 0.933 \\
\hline NFRMI & -2.309267 & 5.679849 & 0.684 \\
\hline TLU & $128.8238^{\star \star}$ & 68.72318 & 0.045 \\
\hline IMC & $683.1827 * \star$ & 89.17521 & 0.000 \\
\hline _cons & 286.0654 & 136.291 & 0.027 \\
\hline Mills or lambda & -191.2347 & 75.41281 & 0.012 \\
\hline
\end{tabular}

Note: *** and *** at $10 \%, 5 \%$ and $1 \%$ significance level respectively.

Source. Model output based on survey data, 2019

\section{Conclusions and recommendations}

Milk value chain analysis of the study areas revealed that the main value chain actors are input suppliers, dairy producing farmers, rural wholesalers, retailers, collectors, cafes and consumers. There are also governmental supportive actors who support dairy value chain directly or indirectly these are the district agricultural office. Collectors were engaged in purchasing milk from remote areas and sell to retailers and consumers in town market. Rural wholesalers purchase milk from producers and milk collectors and sell directly to retailers, urban wholesalers and cafes. Retailers purchase milk from collectors, producers, collectors urban and rural wholesalers and sell to consumers. Cafes also purchase from collectors, rural and urban wholesalers and directly sell to consumers. 
Regarding the cost of the value chain actors, milk producers in the study areas incur costs mostly during production periods rather than marketing their produce. Producer's profit margin was very low because of high production cost. As compared to each channel from all value chain, actor's cafes take the highest share of profit of 8.49 Birr per liter. Retailers also shared the second profit margin than other actors.

The model result shows that, age, crop income, distance to the nearest milk market and total livestock unit influenced producers' market participation significantly negatively and positively respectively. Moreover, the result indicated that marketed milk volume was also affected by improved dairy cows, land size and tropical livestock unit significantly and positively. So governments and other stakeholders must improve the breeds of dairy cows to increase milk production.

Those farmers who have another adequate crop income generates but not know the value or the advantage of milk income benefits those farmers who must change their production system to milk products as because of demand of milk products increases. Other farm income of crop may be destroyed by natural damage and may be seasonal so, this production of dairying of damage is controlled, and owning of land is scarce from the district.

Distance to the nearest milk market influences marketed milk volume negatively. Because milk producers living were far from the milk market, rather than supplying in to the market consume directly. Separating butter and selling butter and consuming the other dairy product will be the best alternative advantageous. And also governments and those stakeholders may repair the road, give training on how to add value and supply modern milk transporting materials to decrease spoilage. Tropical livestock unit also affect probability of market participation and volume of milk marketed positively and significantly. Since livestock diseases and shortage of water supply are major challenges to livestock production in the study area, governments and other stakeholders involvement of improved livestock types, disease resistant and adaptable species, veterinary services and adequate water supply should be provided by the responsible bodies of governments and NGO with farmers of dairy producers.

As a result of this focus is needed towards this problem and to give solutions to those milk producers. As a result, the government can strength and giving technical supports in dairy production of the district may change the livelihood of those farmers especially organizing the milk producers in cooperative mostly benefit the milk producer farmers, which is effective in Gemechis district and sharing this experience among other district is better. Milk traders also have many problems with quality control technology, milk containe inputs unfair computation with other traders, transportation problem with shortage of transportation and high cost.

\section{References}

1. CSA (Central Statistical Agency) (2019) Area and production forecast of major crops: agricultural sample enumeration surveys, various issues, Addis Ababa, Ethiopia
2. Kuma B (2013) Market access and value chain analysis of dairy industry in Ethiopia:The case of Wolaita Zone. Dissertation Thesis Submitted to, Haramaya University, Haramaya, Ethiopia. Link: https://bit.ly/2AknWug

3. Taye Z (2017) Determinants of milk marketed supply and channel choices in Ethiopia: The case of East Wolaita Zone.M.Sc. Thesis, Haramaya University, Haramaya, Ethiopia.

4. Holloway GC, Nichlson C, Delgado C, Staal S, Ehui S (2000) How to make milk market: A case study from Ethiopian high lands. Socio-economic and policy research working paper 28. ILRI, Nairobi, Kenya. 85. Link: https://bit.ly/2ZkS7dm

5. Clodius RL, Muller MR (1961) Market structure analysis as an orientation for Research Countries. Marketing series 2, Chartham, UK: Natural resource Institute.

6. Sosina Bezai (2016) Analysis of milk value chain: The case of East Hareghe Zone of Oromia , Ethiopia. M.Sc. Thesis, Haramaya University, Haramya Ethiopia.

7. Yamane T (1967) Statistics, an introductory analysis: 2nd edition. New York, Harper and Row. Link: https://bit.ly/31vxBtd

8. Heckman J (1979) Sample selection bias as a specification Error Econometrica 47: 153-161. Link: https://bit.ly/3eKwJok

9. Anandajaya sekeram, P. and Berhanu Gebremedhin (2009) Integrating Innovation Systems Perspective and Value Chain Analysis in Agricultural Research for Development: Implications and Challenges. Improving Productivity and Market Success (IPMS) of Ethiopian Farmers Project Working Paper. International Livestock Research Institute, Nairobi, Kenya.16: 67. Link: https://bit.ly/2ZpVuzw

10. Tegegn A (2013) Value chain analysis of vegetables: The case of habro and kombolcha Woredas in Oromia Region, Ethiopia. MSc Thesis, Haramaya University, Haramaya, Ethiopia. Link: https://bit.ly/38cUp2d

11. Dinku A, Abebe B, Lemma A, Shako M (2019) Beef cattle value chain analysis: Evidence from West Hararghe zone of Ethiopia . Int J Agric Sc Food Technol 5 077-087. Link: https://bit.ly/2BQ2NbF

12. Adesiyan OF, Adesiyan AT, Oluitan RO (2012) Market supply response of cassava farmers in Ile-Ife, Osun State. Canadian Social Science 61-63. Link: https://bit.ly/2NUqYst

13. Gessesse A (2009) Analysis of fruit and vegetable market chains in Alamata Southern Zone of Tigray: The case of onion, tomato and papaya. MSc Thesis, Haramaya University, Haramaya, Ethiopia. Link: https://bit.ly/3g9nxKr

14. AGP-LMD (Agricultural Growth Project-Livestock Market Development) (2013) Value Chain Analysis for Ethiopia: Meat and Live Animals, Hides, Skins and Leather and Dairy; AID-663-C-12-00009. Link: https://bit.ly/38cWFGy

15. Alemayehu Y, Adicha A, Mengistu M, Eshetu B (2016) Assessments Of Market Oriented Beef Cattle Fattening System Under Farmer Management Condition In South Omo Zone Of SNNPR. Current Research in Agricultural Sciences 3 31-45. Link: https://bit.ly/2BpBoNN

16. Azage T, Berhanu G, Hoekstra D (2010) Livestock input supply and service provision in Ethiopia: Challenges and opportunities for market oriented development. Improving Productivity and Marketing Success of Ethiopian farmers. project Working Paper 20. (ILRI). International Livestock Research Institute, Nairobi, Kenya 48. Link: https://bit.ly/2CVHuGh

17. Bassa Z, Alemu T (2018) Value chain analysis of beef cattle production in Wolaita zone: the case of Damot Gale district, Wolaita Sodo and Areka town, Southern Ethiopia Areka Agricultural Research Center, Ethiopia. Journal of Food Nutrition Population Health, 2. Link: https://bit.ly/2NGFkMN

18. Duguma B, Tegegne A, Hegde BP (2012) Smallholder livestock production system in Dandi District, Oromia Regional State, Central Ethiopia. Global Veterinaria 8: 472-479. Link: https://bit.ly/31wL3gu

Citation: Kebede AL, Dinku A, Shako M (2020) Value chain analysis of smallholder milk producer in West Hararghe Zone, Ethiopia. Int J Agric Sc Food Technol 6(2): 093-100. DOI: https://dx.doi.org/10.17352/2455-815X.000061 
19. Gebremedhin B, Jaleta M (2010) Commercialization of Smallholders: Does the market orientation translate into market participation? ILRI (International Livestock Research Institute), Addis Ababa, Ethiopia. Link: https://bit.ly/2VuBSt6

20. Carmen F (2006) Ethiopian Borena and Southern Somali areas livestock value chain analysis report. Pastoralist Livelihood Initiative Livestock Marketing Project. ACDI/VOCA. Addis Ababa, Ethiopia. Link: https://bit.ly/3ie7xZn

21. Taddese G, Yilma Z (2018) Survey of traditional cattle production systems and preferred cattle functions in North and South Wollo Zones, Ethiopia. Ethiop Vet J 9: 91-108. Link: https://bit.ly/3ePewG3

22. McCormick D, Schmitz H (2001) Manual for Value Chain Research on Home workers in the Garment Industry. Brighton, Institute of Development Studies. Link: https://bit.ly/3ieQ7Mc

23. Nganga SK, Kungu J, de Ridder N, Herrero M (2010) Profit efficiency among Kenyan smallholders milk producers: A case study of Meru-South district, Kenya. African Journal of Agricultural Research 5: 332-337. Link: https://bit.ly/2NHkgFV

24. Nuri L (2016) Value Chain Analysis Of Enset (Ensete Ventricosum) In Hadiya Zone, Southern Ethiopia. Dissertation, unpublished, Haramaya University.

25. Onoja OA, Usuroh BB, Adieme TD, Deedam JN (2012) Determinants of market participation in Nigerian small-scale fishery sector: Evidence from Niger Delta region. J Sustain Dev 9: 69-84. Link: https://bit.ly/31zjPWj
26. Perkins C (2013) Challenges to Ethiopia's Cattle and Beef Chain. The International Livestock Research Institute (ILRI). Link: https://bit.ly/3giuGIx

27. Pingali $P$, Meijer M (2005) Commercializing small farm: Reducing the transaction costs. ESA working paper No (05-08) Agricultural and development economics division, Food and Agriculture Organization of the United Nations. Link: https://bit.ly/2VrFSuj

28. Shambel B (2013) Analysis of cattle value chain: The case of Wolaita Zone of SNNPRS, Ethiopia (Doctoral dissertation, Haramaya University, Ethiopia).

29. Tadesse A (2011) Market chain analysis of fruits for Gomma woreda. Jimma Zone, Oromia National Regional State. Link: https://bit.ly/2NHljFR

30. Tadesse E, Tucho TA, Feyisa H, Gashaye W, Tatek W, et al. (2014) Traditional cattle production in the highlands of Hararge: Case study for East and West Zones of the high lands of Harerge, Eastern Ethiopia. Link: https://bit.ly/2NJXHAC

31. Tegegn A (2013) Value Chain Analysis of Vegetables in Habro and Kombolcha Woredas In Oromiya region, Ethiopia: M.Sc Thesis Presented to the School of Graduate Studies of Haramaya University, Ethiopia.

32. Thakur DS, Harbans L, Thakur DR, Sharma KD, Saini AS (1997) Market supply response and marketing problems of farmers in the Hills. Indian Journal of Agricultural Economics 52: 139-150.

\section{Discover a bigger Impact and Visibility of your article publication with}

\section{Peertechz Publications}

\author{
Highlights \\ * Signatory publisher of ORCID \\ * Signatory Publisher of DORA (San Francisco Declaration on Research Assessment) \\ * Articles archived in worlds' renowned service providers such as Portico, CNKI, AGRIS, \\ TDNet, Base (Bielefeld University Library), CrossRef, Scilit, J-Gate etc. \\ * Journals indexed in ICMJE, SHERPA/ROMEO, Google Scholar etc. \\ - OAI-PMH (Open Archives Initiative Protocol for Metadata Harvesting) \\ * Dedicated Editorial Board for every journal \\ * Accurate and rapid peer-review process \\ * Increased citations of published articles through promotions \\ * Reduced timeline for article publication \\ Submit your articles and experience a new surge in publication services \\ (https://www.peertechz.com/submission).
}

Peertechz journals wishes everlasting success in your every endeavours.

Copyright: (c) 2020 Kebede AL, et al. This is an open-access article distributed under the terms of the Creative Commons Attribution License, which permits unrestricted use, distribution, and reproduction in any medium, provided the original author and source are credited. 